\title{
HISTORICAL SOURCES BEARING ON SAMUEL BOGUSLAW CHYLINSKI'S PURSUITS IN ENGLAND AND THE NETHERLANDS AND THEIR ECHOES IN THE GRAND DUCHY OF LITHUANIA
}

\author{
Gina Kavaliūnaité
}

\begin{abstract}
This article presents all known manuscript and printed sources relating to Chylinski's Bible translation, viz. letters written by him to his patrons, the correspondence of his patrons on Chylinski's endeavours, records of the Privy Council, royal briefs for the collection of monies to support Chylinski and the Lithuanian Calvinists in general, and so forth. The author also presents pamphlets by Chylinski advertising his project, published in Oxford and London. Many of these sources, discovered by the author, have not been used in previous studies.
\end{abstract}

In the final decades of the 16th century, the Calvinist community of Lithuania sought permission for the establishment of an institution of higher learning in Vilnius, but their endeavours, having met with the opposition of King Sigismund Vasa and the Catholic Church, were ineffectual. The Calvinist ministers of the Grand Duchy received their education at universities in Germany, France, the Netherlands, Scotland and other countries of Western Europe; on completion of their academic training, most of them returned to their homeland. Samuel Bogusław Chylinski, who had received his schooling at the Kedainiai Grammar school, went for his further education to the Academy of Franeker in the Netherlands, where he matriculated as a student of divinity on 5 May 1654. The same day saw the matriculation, also in divinity, of Gideon Reczynski. They were preceded, two weeks earlier, by Daniel Wegner Fraustad, who enrolled as a student of medicine. All three are listed on the roll of students as Poloni. ${ }^{1}$ Gideon Reczynski returned to Lithuania on completion of his studies: on 7 September 1664, the provincial synod of Kedainiai appointed him as ad interim minister at Węgrów, to replace Jan

${ }^{1}$ A.S.J. Fockema, T.J. Meijer (eds.), Album Studiosorum Academiae Franekerensis (1585-1811, 1816-1844) I. Naamlijst der studenten (Franeker 1968), p. 162. 
Krzysztof Krainski, ${ }^{2}$ who had been sent as a delegate to England; at the 1673 provincial Synod of Vilnius he acted, in quality of minister of Orla, as one of the scribes for the ecclesiastical estate; and two years later he is again mentioned as a scribe at the Vilnius synod, this time as minister of Orla and Bielica. ${ }^{3}$ His fellow-student, Chylinski, stayed in the Netherlands for his further education after Lithuania had been drawn into a war with Sweden and Muscovy, and subsequently moved to England, where he established broad ties and put all his efforts into the service of the Calvinist Church in his homeland. He translated the whole Bible into Lithuanian, sent it to be printed and, first and foremost, furthered the reputation of Lithuania as a cultivated and Christian country.

It was not until the early 19th century that a search was launched for the London Lithuanian Bible, which many catalogues of rare books mentioned, but virtually no one had ever seen. The final decade of that century saw the first publications addressing questions of authorship and translation sources, and establishing and exploiting the sources for Chylinski's life and work. Until then, conjecture concerning the mysteriously fated Chylinski Bible, also known as the London or Lithuanian Calvinist Bible, had been based mainly on references in bibliographical editions, ${ }^{4}$ and on Chylin-

2 The Wróblewski Library of the Lithuanian Academy of Sciences (LMAB RS), F-40-1136, f. 240; LMAB RS F-40-125, f. 46.

${ }^{3}$ LMAB RS, F-40-1136, f. 374, 375; MAB, F-40-125, f. 91v.

${ }^{4} \mathrm{D}$. Clement, Bibliothèque curieuse historique et critique, ou catalogue raisonné de livres difficiles à trouver, vol. 4, (Göttingen, 1750-1760); W. Crowaeus, Elenchus in sacram scripturam tam graecorum, quam latinorum [...] in quo exhibentur eorum gens, patria, professio, religio: librorum tituli, volumina, editiones variae, quo tempore claruerint vel obierint. Elogia item aliquot virorum clarissimorum quibus omnibus praemissa sunt S. Biblia, partesque Bibliorum, variis linguis, variis vicibus edita (London, 1672); F.G. Freytag, Analecta Litteraria de Libris Rarioribus (Leipzig, 1750); J.G.T. Graesse, Trésor des Livres rares et précieux ou nouveau dictionnaire bibliographique: contenant plus de cent mille articles de livres rares, curieux et recherchés, d'ouvrages de luxe etc., vol. 1 (Dresden, 1858); C.G. Jöcher, Allgemeines Gelehrten-Lexicon: darinnen die Gelehrten aller Stände sowohl männ- als weiblichen Geschlechts, welche [...] bis auf ietzige Zeit gelebt [...] aus den glaubwürdigsten Scribenten [...] in alphabetischer Ordnung (Leipzig, 1750); C. Kortholt, De Variis Scripturae Editionibus Tractatus Theologico-Historico-Philologicus: Quo de Textu divinarum literarum originario, diversis eius Translationibus, \& celebrioribus operibus Biblicis, fuse agitur, quaeque de Scripturarum fontibus, versione LXXvirali, Targumim, ac Latina Vulgata, Card. Bellarminus, huiusque propugnatores, Jacobus Gretserus \& Vitus Erbermannus, minus recte disputant, solide refelluntur (Kiel, 1686); J. Le Long, Bibliotheca Sacra Seu Syllabus Omnium Fere Sacrae Scripturae Editionum Ac Versionum secundum 
ski's rendering of the Lord's Prayer, which had found its way into many European polyglot Bildes. ${ }^{5}$ The first historians who had more ample source material at their command were Józef Łukaszewicz ${ }^{6}$ and Maurycy Stankiewicz. ${ }^{7}$ But even their sources were confined almost exclusively to the records of the Lithuanian Calvinist synods, and one is hardly surprised at seeing them groping in the dark about the authorship of the London Bible, considering how few the mentions of Chylinski's work are in the synodal minutes. The first scholar to reach for primary sources in unravelling the history of the Chylinski Bible was Heinrich Reinhold, ${ }^{8}$ who published the results of his research in Mitteilungen der Litauischen Litterarischen Gesellschaft. Apart from doing justice to the sources, he compared Chylinski's translation with that of Bretke, and published Chylinski's letter to the Oxford University professor Henry Wilkinson. Further signal advances in the investigation of the Chylinski Bible and its history are due to Stanisław Kot. It was he who identified Chylinski's manuscript translation of the New Testament, discovered in the British Library and the Bodleian several letters dispatched to England by the Lithuanian Calvinists, as well as a letter from Chylinski to John Wallis, and pointed to traces of Chylinski's activities in England in the Privy Council records. ${ }^{9}$ Several decades later, Ingè Lukšaitè

seriem linguarum quibus vulgatae sunt Notis Historicis Et Criticis Illustratus [...] Labore \& industria Jacobi Le Long [...] Totum opus cum additamentis, suo loco In Nova Hac Editione colloratis ... notisque auxit Christianus Fridericus Boernerus (Leipzig, 1709); J. Vogt, Catalogus Historico-Criticus librorum rariorum sive ad scripta hujus argumenti: Spicilegium, index et accessiones (Hamburg, 1732); L.M. Widekind, Ausführliches Verzeichnis von raren Büchern (Berlin, 1735); H. Witte, Diarium Biographicum, in quo scriptores seculi post natum Christum XVII. praecipui [...] magno adducuntur numero (Gdańsk, 1688).

${ }^{5}$ For an overview of books containing Chylinski's rendering of the Lord's Prayer cf. G. Kavaliūnaitè, 'Samuelio Boguslavo Chylinskio „Tève mūsų“ tradicija Europos poliglotiniuose leidiniuose', Archivum Lithuanicum, 3 (2001), pp. 345-54.

${ }^{6}$ J. Łukaszewicz, Dzieje kościołów wyznania helweckiego w Litwie, 2 (Poznań, $1843)$.

${ }^{7}$ M. Stankiewicz, Wiadomość o Biblii Litewskiéj, drukowanéj w Londynie 1663 roku, i o wrzekomym jéj tłómaczu Samuelu Bogusławie Chylińskim (Kraków, 1886).

${ }^{8} \mathrm{H}$. Reinhold, 'Die sogenannte Chylinskische Bibelübersetzung', Mitteilungen der Litauischen Litterarischen Gesellschaft, 4, Heft 2 (20) (Heidelberg, 1895) pp. 105-63.

H. Reinhold, 'The London Lithuanian Bible', The Academy, 461 (30 11 1895).

H. Reinhold, 'Die Bibelübersetzung von Chylinski', Mitteilungen der Litauischen Literarischen Gesellschaft 4, Heft 3 (21) (Heidelberg, 1896), pp. 207-73.

9 S. Kot, 'Chyliński Bogusław Samuel', Polski Słownik Biograficzny, vol. 4 (Kraków, 1938), pp. 11-12. S. Kot, 'Chylinski's Lithuanian Bible: Origin and Historical Background', Biblia litewska Chylińskiego. Nowy Testament, vol. 2 (Poznań, 1958) pp. 43-67. 
discovered Krainski's account of his money-raising actions in England in the library of the Lithuanian Academy of Sciences, and published a transcript of it. ${ }^{10}$ To Ingè Lukšaitė we further owe a transcript and a Lithuanian translation of Chylinski's pamphlet Ratio Institutae translationis Bibliorum in Linguam Lithuanicam, preceded by an introductory article and commentaries. ${ }^{11}$ A comprehensive overview of research into the history of the Chylinski Bible can be found in the introduction to the facsimile edition of Chylinski's Old Testament. ${ }^{12}$

Recent years have yielded a considerable body of new sources unknown to earlier investigators. Newly discovered documents have complemented the results of previous research and shed a new light on many facts. They have made it possible to establish the exact date as well as the circumstances of Chylinski's death, and to identify his burial place; documents have been found evidencing the course of the collections held towards the printing of the Lithuanian Bible and the reconstruction of Lithuanian churches; the role played by Krainski in stopping the printing of Chylinski's Bible, hitherto merely conjectured by researchers, has now been confirmed; hitherto unnoticed circumstances conducive to the abandoning of the printing of the Chylinski Bible have been brought to light; it has become clear that not only the obstacles raised by Krainski and a Lithuanian Calvinist Synod supportive of him, but above all the broader political and social context of the England of those days sealed the demise of this undertaking.

In this article, we give an overview of the sources at present available for the history of the Chylinski Bible. Chylinski's pursuits in England are reflected in letters, Privy Council records, Royal letters patent and memoranda, lists of briefs, lists of proceeds from collections, printed publications (one by Krainski and two by Chylinski), a petition for the reimbursement of expenses towards Chylinski's care and burial, and records in church registers. How

${ }^{10}$ I. Lukšaite, 'Lietuviškos S.B. Chilinskio biblijos spausdinimo aplinkybės', Lietuvos TSR Moksly akademijos darbai, A serija 1 (35), 1971, pp. 87-109.

${ }^{11}$ I. Lukšaitè, 'Samuelio Boguslavo Chilinskio „Biblijos vertimo i lietuvių kalbą pagrindimas"', Knygotyra, 36 (2000), pp. 248-74.

12 G. Kavaliūnaitè (ed.), Samuelio Boguslavo Chylinskio Biblija. Senasis Testamentas, I tomas: Lietuviško vertimo ir olandiško originalo faksimilès = Vetus Testamentum Lithvanicâ Lingvâ donatum a Samuelo Boguslavo Chylinski. Unâ cum texto belgico (Vilnius, 2008). 
echoes of Chylinski's work reached the Grand Duchy can be seen from letters sent by the Lithuanian Calvinists to England, records of the Lithuanian Calvinist synods, and from the account which Jan Krzysztof Krainski, a delegate of the Lithuanian Reformed community to England, gave of collections held in England.

\section{Sources held by British libraries}

Letters written by Chylinski The archives hold letters written by people who supported Chylinski's aim and lent assistance to the translator of the Lithuanian Bible, and letters written to them by Chylinski. The following letters have come down to us: Chylinski to Wilkinson (7 February 1659), ${ }^{13}$ Chylinski to Boyle (1 June 1660), ${ }^{14}$ Chylinski to Wallis (4 October 1662 and 19 October 1664), ${ }^{15}$ and one letter to an unidentified person inscribed on one of the back pages of the manuscript of the New Testament translation. ${ }^{16}$ Unfortunately, the letters which Chylinski received from his supporters are not extant.

The prevailing view in the literature on Chylinski is that his principal patron in England was the Prussian-born English polymath Samuel Hartlib, brother of Georg Hartlib, who was rector of the Reformed Grammar school of Vilnius. Hartlib was probably instrumental in Chylinski's getting acquainted with several Oxford professors, as well as with Robert Boyle, but no letters from Chylinski have been found until now in Hartlib's impressive body of correspondence. On the whole, Hartlib did not engage in patronage; his role lay, first of all, in transmitting ideas, bringing people together and helping them establish ties.

On examination of the extant body of sources, we see that during Chylinski's first years in England, his principal well-wisher, to whom the young student of divinity just arrived from Franeker and inspired with the wish to translate the Scriptures into the little-known Lithuanian tongue, could turn for support seems to have been Henry Wilkinson, an Oxford professor and preacher at Magdalen Hall. It is to him that Chylinski's earliest extant letters are addressed. Together

\footnotetext{
${ }^{13}$ Bodleian Library (BodlL) Tanner, MS 51, fol. 40 and BodlL Add 105.

${ }^{14}$ Royal Society (RS), RB/3/2/7.

15 BodlL Add. D. 105, F. 12, 13, 16, 17.

${ }^{16}$ British Library (BL), MS 41301.
} 
with the University's vice-chancellor, divinity professor John Conant, Wilkinson assembled a group of people willing to support the pursuits of the translator of the Lithuanian Bible, sought to raise money for his undertaking, and arranged for a recommendation to be issued to the translator of the Lithuanian Bible by a number of Oxford professors and other prominent personalities. Most of those who signed it (such as the Oxford professors Edward Pococke, Seth Ward, John Wallis, Henry Wilkinson, John Conant and others) were distinguished figures in scholarly life.

Later on, it was John Wallis, Savilian professor of geometry and a close associate of both Wilkinson and Conant, who was to become Chylinski's most devoted patron. He acquainted Robert Boyle, the father of modern chemistry, with Chylinski's undertaking. Boyle burned with the idea of having the Bible translated into vernacular languages: he personally lent financial and moral support to Turkish, Malay and Irish translations of the Bible, and, as can be gathered from the extant letter Chylinski addressed to him, must also have supported the translator of the Lithuanian Bible financially on more than one occasion. Having been apprised of the conflict that had arisen between Chylinski and the Lithuanian delegate, he inquired into its causes, and, as far as we can judge from the synopsis which Wallis prepared at his request, firmly took Chylinski's side and was determined to save the Lithuanian Bible project. Why he failed to do so is a question we cannot answer in the present state of our knowledge.

On several occasions, Chylinski turned to John Wallis for support and advocacy, and he kept him informed of his successes and disappointments. In an extant letter, Chylinski begs Wallis to attend a Privy Council meeting (to be held in October 1662), at which Chylinski's complaint about the unjustified obstruction of the printing of the Bible is to be heard, and in the autumn of 1664 , Chylinski, already despairing of seeing his translation in print, writes to Wallis to thank him for an earlier letter and to tell him that he was denied access to Whitehall, though he had an appointment with Richard Browne.

The extant Privy Council records yield no evidence of Chylinski's attendance at any of the meetings, but we know that he lodged a complaint with the Council about the discontinuation of the printing of the Bible, and he himself mentions an earlier visit to the Privy Council. There is an extant copy of a summons from 
Richard Browne ${ }^{17}$ for Chylinski to attend a Privy Council meeting (3 October 1662), and of Chylinski's answer to Richard Browne (4 October 1662). ${ }^{18}$ This suggests that it was Browne who heard Chylinski's complaint about Krainski's obstruction of the printing process. The summons to appear before the Privy Council was delivered to Chylinski on the eve of the hearing, so that he did not have time duly to prepare and to seek the assistance of people who could have advocated his cause. This circumstance raises the question of Browne's possible partiality in dealing with this case. Chylinski lodged a written request for the hearing to be postponed for a week and for a person of renown, who could plead his case, to be admitted to it. If this hearing actually took place, it did not yield any results.

Letters exchanged between Chylinski's patrons We refer here to one letter from John Wallis to Robert Boyle ${ }^{19}$ and to letters exchanged by Samuel Hartlib, John Worthington, Henry Oldenburg and others.

References to Chylinski's translation of the Bible are scattered over the letters of quite a number of scholars of his days, and they testify to the significance these people attached to Chylinski's undertaking in a broader cultural context. One of the central figures in their correspondence was Samuel Hartlib, who had launched the publication of handwritten newsletters in the 1630s. The purpose he cherished - the dissemination of new ideas - subsequently became one of the objectives of the Royal Society (established in 1660), and we may regard him as one of the initiators of the international network of correspondents bent on exchanging scholarly ideas that has become known under the name of the Republic of Letters

${ }^{17}$ Richard Browne was a former officer in the Parliamentary army who distinguished himself during the Civil War. From 1647 onwards he vigorously opposed the seizure of the King and began to use his influence to defend the King against the designs of the Congregationalists. In 1648 he was expelled from the House of Commons for his connivance with the Scots, and a year later he was prevented from taking his seat in the Second Protectorate Parliament. In 1659 he was to be restored to his posts but came under suspicion of involvement in Booth's Uprising and had to go into hiding. After the Restoration he showed himself a Royalist, was awarded with a knighthood and a baronetcy, restored to the Council of Aldermen and led Charles II's procession into London.

18 BodlL Add. D. 105.

${ }^{19}$ RS BL 6, f. 11r-12v. 
(Respublica literaria). ${ }^{20}$ Most of the texts in which we find references to Chylinski have been published in special collections. Until now, such references have been found in the following:

Samuel Hartlib to Dr John Worthington (17 January 1659) ${ }^{21}$

Samuel Hartlib to John Worthington (30 January 1659) ${ }^{22}$

Henry Oldenburg to Saporta (19 February 1659/60) (3) $^{23}$

John Worthington to Samuel Hartlib (28 May 1661) ${ }^{24}$

John Dury to Samuel Hartlib (28 June 1661) ${ }^{25}$

John Worthington to Samuel Hartlib (2 December 1661) ${ }^{26}$

Samuel Hartlib to John Worthington (7 December 1661). ${ }^{27}$

The most remarkable of these letters is one written by John Wallis, the first great English mathematician to emerge since Newton, to Robert Boyle (14/24 March 1661/62). ${ }^{28}$ At Boyle's request, Wallis collected all the facts accessible to him about Chylinski's studies and his times in England, and on the basis of his findings,

${ }^{20}$ The so-called 'Republic of Letters' existed for more than 300 years, from the Renaissance to the Enlightenment, and is defined as a network of correspondents and an intellectual community that helped shape the early modern age. It had no legal status and existed only in minds. Between the 16th and the 18th centuries, intellectuals regarded themselves as members of an international community dedicated to the diffusion of new ideas through the printed word, and to furthering progress in the sciences. They collected, classified and disseminated knowledge, grouping themselves around institutions of learning, libraries, museums, academies and universities. Differences of opinion and interpretation were no hindrance for the accumulation of knowledge and the realisation of intellectual projects. This network of correspondents extended to Russia and - through the involvement of missionaries and affluent merchants - even Asia and America. (Cf. C.M. Furey, Erasmus, Contarini, and the Religious Republic of Letters [Cambridge, 2006]; M. Ultee, 'The Republic of Letters: Learned Correspondence 1680-1720', Seventeenth Century, 2 [1987], pp. 95-112).

${ }^{21}$ Published in: J. Crossley, The Diary and Correspondence of Dr. John Worthington, Master of Jesus College, Cambridge, Vice-Chancellor of the University of Cambridge, vol. I (Printed for the Chetham Society, 1847), pp. 180-1.

22 Idem, pp. 16-177.

${ }^{23}$ Published in: A.R. Hall, M.B. Hall, The Correspondence of Henry Oldenburg, I (The University of Wisconsin Press 1965) p. 353.

24 Published in: Crossley, The Diary, I, pp. 312-4.

25 Partly published in: S. Kot, 'Chylinski's Lithuanian Bible', p. 60.

${ }^{26}$ Published in: Crossley, The Diary, II, pp. 74-8.

${ }^{27}$ Idem, pp. 81-7.

${ }^{28}$ RS, BL 6, F. 11r-12v. A transcript was published by M. Hunter, A. Clericuzio, L.M. Principe (eds.), Robert Boyle Reconsidered (Cambridge, 1994), pp. 7-10; P. Beeley, C.J. Scriba (eds.), The Correspondence of John Wallis, Vol. II (Oxford, 2005), pp. 7-10. 
his own observations and his personal contacts with the translator of the Lithuanian Bible, he gives a synopsis of Chylinski's life and pursuits in England and the circumstances attending them. This letter, hitherto overlooked in the literature on Chylinski, brings to light a number of facts confirming the surmise that the Lithuanian delegate Jan Krainski's narrow-mindedness, his lack of understanding of the need for a Lithuanian Bible, his selfish interests and his scheming, were behind the unfortunate end that befell the Chylinski Bible.

\section{The collections, the Royal letters patent, the Privy Council re-} cords, the memorandum, entries confirming receipt of briefs, the lists of proceeds from collections. Soon after Chylinski's patrons had presented a petition to King Charles II requesting a collection to be held towards the further printing of the Lithuanian Bible, a delegate of the Lithuanian Calvinist Synod, Jan Krzysztof Krainski, arrived in Britain bearing official credentials and a (non-extant) letter of recommendation from Bogusław Radziwiłł. The purpose of his journey was to seek financial support for the reconstruction of Lithuanian Reformed churches devastated in the war. It was only on his arrival in London that he learnt about Chylinski's accomplishments in translating the Bible, the circle of patrons assembled about him, and the esteem he enjoyed. Krainski immediately set out appropriating the credit for Chylinski's achievements and turning them to his advantage. While representing the idea of the Bible translation as emanating from the Lithuanian Synod, he at the same time ignored the actually accomplished translation and sought to manoeuvre its author out of the way. Together with delegates from other countries, Krainski was granted an audience with the King. These events almost coincided in time with the petition for a collection towards the printing of the Bible. Having persuaded Chylinski to go to Lithuania to report to the Synod and to submit his Bible translation for scrutiny, Krainski undertook to represent two causes before the Privy Council - that of the Lithuanian Bible, which was actually Chylinski's concern, and that of relief for the Lithuanian churches, which he had been commissioned to plead. The Royal letters patent, which were drawn up under the supervision of Richard Browne, Privy Council secretary and member of the Court of Aldermen, who was also responsible for the course of the collections, state as their foremost object the furtherance of the printing of the Lithuanian Bible, while allowing the remainder of 
the collected sums to be applied to relief for the Lithuanian churches. ${ }^{29}$ Nowhere in the letters patent is the name of the translator mentioned; only Krainski figures as the Lithuanian delegate. Later on, in his report to the Calvinist Synod, Krainski would express his regret for not having succeeded in expunging the printing of the Bible from the list of objects of the collection. Though it was well known among scholars that "not Krainsky, but one Chilinski is the principal actor in that affair, who is lately returned to England to prosecute that business, being a professed Lithuanian', it was the official delegate's word that was relied upon in those circles where the financial decisions were taken. ${ }^{30}$

Collections for various charitable purposes, such as repairs to churches, relief for victims of calamities, support for brethren in the faith abroad, or the redeeming of prisoners, had become a tradition in England from the early Reformation onward. Whenever an object worthy of a collection was brought forward, a petition was submitted to the King by at least two trustees or churchwardens. The King authorised collections by letters patent, of which briefs were then distributed among the parishes. ${ }^{31}$ There was a sharp increase in the number of briefs issued after the Restoration, and after 1660 the issue of briefs was deliberated upon no longer by the Privy Council. ${ }^{32}$ In the case of the Lithuanian Bible, Royal letters patent were issued on 12 July 1661, briefs were sent round to the parishes, and a separate memorandum was adopted to the effect that this Royal decree was not to become a precedent: 'It was this day ordered by his Majestie in Councill, That the Breife for Collection for the protestant Churches in Lihuania now recommended to the Sheriffs (as above) by Letters from the Lords of his Majesties most Honourable privy Councell, be no precedent for the like Letters here after, this case being singular, \& therefore deserving this extraordinary

29 The only extant copy known at present is in the British Library, shelfmark Luttrell III (27). In 1684 a resolution of the Kedainiai Provincial Synod (LMAB RS, F 40-125, f. 153v) requested Krainski to depose his own copy of the letters patent, bearing the Royal seal, in the Great Archive of the Synod. What has become of this copy is not known.

${ }^{30}$ Hartlib to Worthington, 7 December 1661 (Cambridge University, Worth/70).

31 T.N. Postlethwaite, Some Notes on Urswick Church and Parish. With Extracts from the Old Church Books, and a List of Briefs, Some Hitherto Unnoted (Ulverston, 1906), p. 14.

32 W.A. Bewes, Church Briefs on Royal Warrants for Collections for Charitable Objects (London, 1896), p. 21. 
favour. ${ }^{33}$ By the second half of the 17 th century, the practice of applying for briefs had become so widespread that people began to doubt their charitable purposes. ${ }^{34}$ The undertakers began to demand administration fees, and the whole degenerated into a trade often referred to as 'farming'. The undertakers' abuses took such forms that often instead of relief money the community that had applied for support received a debt claim for outstanding administration fees. ${ }^{35}$ As we can see from certain entries in the Privy Council records, Krainski also received fees for the supervision of the collections in addition to his salary.

On several occasions, starting from 24 January 1661, the Privy Council heard petitions relating to the relief action for Lithuanian Protestants. ${ }^{36}$ This business was brought up at nine meetings which took place between 24 January 1661 and 3 March 1664. The first five meetings, which took place before 25 February 1662, were attended by the King himself. The main questions considered concerned payments from the proceeds of the collections to Jan Krzysztof Krainski or, less frequently, to other persons. At the last of the meetings on record, on 3 March 1664, the Privy Council heard Chylinski's complaint about the treasurer's refusal to pay him the allowance the Privy Council had granted him. As far as we can judge from Krainski's account, it is the official Lithuanian delegate and supervisor of the collections who had thus instructed the treasurer.

The archives of several English parishes have recently yielded lists of receipts for briefs with appeals for relief for the Lithuanian Protestants, ${ }^{37}$ as well as several lists of proceeds from the collections. ${ }^{38}$ We know that collections were held throughout the kingdom,

${ }^{33}$ National Archives (NA), PC 2-55, p. 536.

${ }^{34}$ In support of this claim the following entry from Samuel Pepys' diaries (30 January 1661) is often quoted: '30th June 1661 (Lord's Day). To church, where we observe the trade of briefs is come now up to so constant a course every Sunday, that we resolve to give no more to them' (cited from Bewes, Church Briefs..., p. 21).

35 Postlethwaite, Some Notes, pp. 37-8.

${ }^{36}$ NA, PC 2-55, 56.

${ }^{37}$ Longleat House, TH/VOL/LXIII.

${ }^{38}$ Gloucestershire Archives, Chedworth Parish Registers 1653-1692, shelfmark P77/IN/1/1; Gloucestershire Archives, Aston-sub-Edge Parish Registers 1539-1719; Bury Record Office, Suffolk County Council, shelfmark FL627/4/1 (1538-1728); Herefordshire Archives, Bridstow Parish Registers, shelfmark AC84/1; Cambridgeshire Archives, Boxworth Parish Registers 1588-1712, shelfmark P15/1/1. 
and that briefs were sent to every parish of England and Wales. The briefs issued for the Lithuanian Protestants were of a particular type, in that they authorised the churchwardens not only to take the collection during services but also to raise money on a house-to-house basis. There is slight doubt that similar lists of briefs and collection proceeds can be found in many other parish archives.

Printed sources An important source for the history of the Chylinski Bible and Chylinski's work in England is the booklet he published in two languages, English and Latin, and whose English title is $A n$ Account of the Translation of the Bible into the Lithuanian Tongue [...], Oxford: Henry Hall, 1659. ${ }^{39}$ In this booklet, Chylinski argues the need for a printed Lithuanian Bible, gives an overview of earlier publications of the Lithuanian Protestants, and lists a few further books he thinks should be translated into Lithuanian in addition to the Bible. Apart from Chylinski's Account, the booklet also contains a recommendation entitled Copy of the Testimonial given to the Translator, and to the approbation of his undertaking, by several Reverend Doctors of Divinity, with the Professors of the same, and other Persons of Note, in the University of Oxford. ${ }^{40}$ Both texts have already been discussed in the literature. ${ }^{41}$ What has hitherto escaped the attention of historians of the subject is that the delegate of the Lithuanian Reformed Synod, Jan Krzysztof Krainski, also published a pamphlet to promote his cause; in this case, the aim was evidently to move the British public to compassion and charitableness. This booklet, of which I have been able to locate only one copy (in the Shakespeare Library in Washington) is entitled $A$ Relation of the Distressed State of the Church of Christ, Professing the Protestant Religion in the Great Dukedom of Lithania, Presented

39 Three extant copies are known: BL 12. 14. a. 5; BodlL (shelfmarks: Wood B 37(2) and C13. 6. (47) Linc).

40 The Latin version was published about 1660/1: (S.B. Chylinski), Ratio Institute Translations Bibliotrum in Linguam Lithvanicam [...], (Oxford, 1660/1); it bears a dedication to a number of prominent figures among the Lithuanian Calvinist community and also contains the text of the recommendation issued to Chylinski by the Rector of the Franeker Academy (Rector Magnificus \& Senatus Academiae Frisiorum quae est Franequerae, lectori Salutem in Domino). Two extant copies are known: in Uppsala University Library (Språkvet. Allm. Grafik [58:222]) and in Copenhagen University Library, shelfmark 20, 45 00588; the latter was recently discovered by Prof. Férenc Postma.

${ }^{41}$ Kavaliūnaite, 'Introduction', in: Kavaliūnaitè (ed.) Samuelio Boguslavo Chylinskio Biblija, pp. 73-128; Lukšaitè, 'Samuelio Boguslavo Chilinskio', pp. 248-74. 
to the view of all Compassionate Christians (London, 1661). ${ }^{42}$ The printer is unknown. In many respects, this pamphlet is reminiscent of Chylinski's Account; the author refers to this publication in the report he delivered to the provincial synod of Vilnius. Invoking the support the English had once lent to the Bohemians and the Waldensians, he expresses his hope for a similar munificence of the compassionate British public towards the Lithuanian Protestants. The pamphlet describes, in lurid detail, the atrocities committed by the Muscovites and the Cossacks, dwelling in particular on the death of Samuel Bogusław Chylinski's father, Adrian Chylinski, and other ministers.

Letters sent from the Grand Duchy to England The British Library and the Bodleian between them hold three letters sent by the Lithuanian Calvinist Synod to England. They are addressed to Charles II (24 August 1660) ${ }^{43}$, Richard Browne (1-10 February 1661-2) ${ }^{44}$ and the King's Privy Council (6 December 1663). ${ }^{45}$

The letter written by the Lithuanian Calvinists to King Charles II on St Bartholomew's Day 1660 was delivered by Krainski when he came to England. Inspired by the munificence the English had bestowed on the Piedmontese and other oppressed Protestants, the authors apply for support towards the reconstruction of Lithuanian churches damaged in the wars. The letter is signed by Jan Borzymowski, superintendent of Žemaitija, Andreas Musonius, superintendent of Vilnius, and Teofil Dunin Rajecki, director of the convocation of Kedainiai. In his account, Krainski avers that he also held a letter of recommendation from Bogusław Radziwiłk, but whether it is extant we do not know.

The next letter is addressed to Richard Browne. As a Privy Council secretary, Browne was in charge of supervising collections and distributing briefs calling for collections. On the basis of Krainski's reports, the Lithuanian Reformed Synod had formed the opinion that it was Browne who had arranged for the letters patent and the briefs to be issued, and that he was Krainski's benefactor and adviser in all matters. In the letter, the Lithuanian Calvinists thank their delegate's patron for having secured Royal letters patent, and

\footnotetext{
${ }^{42}$ Shakespeare Library, K750a.

${ }^{43}$ NA, SP/10, f. 244-245.

${ }^{44}$ BL, Add. 15857, f. 156, 157.

45 BodlL, Rawl. C. 984, f. 3-4.
} 
express the hope that, after a long expectation, the assistance proferred by pious English hands and hearts will soon be forthcoming. The letter bears the signatures of Andreas Musonius, superintendent of Vilnius, Jan Borzymowski, superintendent of Samogitia, Martin Bythner, superintendent of the Transvilia district (the region north of the Vilia around Švenčionys), Daniel Reder, consenior of the Nowogródek district, Jan Audziejewicz, consenior of the Vilnius district, and Jan Volinius, consenior of Žemaitija.

The last letter is dated 6 December 1663. It exudes disappointment, as the help so often promised fails to materialise, and anxiety at the lack of news from the delegate in England. The delegate had returned to Lithuania without bringing with him any documents confirming his assurances of forthcoming support from England, excused himself from attending the Synod which took place on 7 June 1663, and, contenting himself with sending a report (or draft report) to the Synod, hastily left again for Britain. The signatories of the letter (three superintendents and six other participants in the Synod) request the Honourable Lords of the Privy Council to apprise them of their decision concerning relief for the oppressed brethren in Lithuania before the next meeting of the Synod, which is to take place in June of the next year.

Ties with the Dutch Church in London Chylinski's contacts with the Dutch Church at Austin Friars are reflected in the records of the Privy Council. The Reverend Cesar Calandrini, a minister and librarian of the Dutch congregation, had lent money towards the translation and printing of the Lithuanian Bible; a Privy Council resolution of 14 February 1661 provides for the reimbursement of this debt. About a year later, we find an entry in the minutes of the Privy Council meeting of 25 February 1662, to the effect that the unused sheets of paper left after the printing of the Bible was stopped at Krainski's behest, as well as the printed sheets of the Bible's text, are to be turned over to the library of the Dutch Church. The fact that the unbound sheets of the printed part of Chylinski's Bible were entrusted to Calandrini is also mentioned in Krainski's report to the Vilnius provincial synod, as well as in a petition submitted to the Privy Council by Edward Phipps and William Medgate of St Giles and Cripplegate, requesting their expenses for Chylinski's care and burial to be reimbursed. We may assume that Chylinski enjoyed Calandrini's full confidence, otherwise he would not have advanced large sums towards work undertaken by an alien from Lithuania. 
Sources for the last years of Chylinski's life The discovery of a petition from Edward Phipps and William Medgate of St Giles and Cripplegate to the Privy Council, ${ }^{46}$ now held by the library of the Royal Society, has shed a reliable light on the last years of Chylinski's life. We now know the exact date of his death, its cause, and his place of burial. The petition is for reimbursement of the expenses incurred for medical treatment, tending and burial of a gentleman who translated the Bible into Lithuanian. We learn from the petition that Chylinski, having fallen seriously ill, had applied to Phipps and Medgate for lodgings and care, producing a transcript of Privy Council records in which the translator of the Lithuanian Bible was promised an allowance towards his subsistence. The petitioners declare they have given Chylinski all the care he needed, and arranged, after his death on 5 July 1666, for his burial in the cemetery of St Giles and Cripplegate. This region in the east of London, extending on both sides of the medieval city wall, was then populated mostly by paupers and aliens, but as the city grew more and more, representatives of the middle classes settled there.

The date of Chylinski's death is also confirmed by an entry in the registers of baptisms, marriages and burials of St Giles-withoutCripplegate. ${ }^{47}$

\section{Sources in Dutch libraries}

Only two sources connected with Chylinski's studies in the Netherlands are extant. One is an entry in the matriculation roll of the Franeker Academy, ${ }^{48}$ the other is a letter of recommendation issued to Chylinski by Christophorus Munsterus, rector of the Franeker Academy, and Gerardus Kaldenbach, its librarian. Chylinski reproduced the words of this recommendation, which also contains an appeal to support the Franeker alumnus in his pious undertakings, at the end of his Ratio.

\section{Sources in Lithuanian libraries}

While English libraries and archives have yielded many documents testifying to Chylinski's work as a translator of the Bible, as well as

${ }^{46} \mathrm{RS}, \mathrm{RB} / 1 / 4 / 18$.

${ }^{47}$ London Metropolitan Archives, P 69/GIS/A/01 MS 6419/7.

${ }^{48}$ Album Studiosorum. Album Academiae Franekerensis. Rectorsalbum nr. 1, 1586-1685. Tressoar nr. 104. 
to his ties with the circle around Samuel Hartlib and with several of the founders of the Royal Society, only a few documents relating to Chylinski are extant in Lithuania. After his departure for Franeker in 1653, Chylinski stayed away from Lithuania until 1661.

Valuable references to the Chylinski Bible can be found in two sources held in Lithuanian libraries: the records of the Lithuanian Calvinist Synod, and Jan Krainski's report to the Synod.

The records of the Lithuanian Calvinist Synod In the records of the Lithuanian Calvinist synods, which regularly brought together the Calvinist clergy and laity, the entries relating to Chylinski's activities span the period between 1654 and 1666. From these entries, we can gather that after Chylinski's departure for studies abroad, little or nothing at all was known about his doings. When the Synod decided, in 1659, to look for financial support in England, nobody thought of putting to use Chylinski's connections, of which nothing was known; instead, the petitioners, in applying for support towards the reconstruction of Protestant churches in Lithuania, invoked the munificence the English had previously shown to the Piedmontese and other brethren in the faith.

Only two resolutions of the Synod are directly connected with Chylinski: in 1653, as Chylinski was unable to embark on his journey to Franeker, where he was to study, the Synod allowed him a year's board and accommodation at Kedainiai; and at the Kedainiai convocation in August 1661, the Synod dealt with Chylinski's translation of the Bible. Chylinski, who attended the Synod, presented his translation, and his work was favourably received. It was decided to have the translation checked by Jan Borzymowski, superintendent of Žemaitija, and by the Reverend Teodor Skrodzki, and to send the revised translation to be printed. It was at this moment, before even Borzymowski and Skrodzki had the time to make any comments, that Krainski, exploiting Chylinski's absence in Lithuania, gave orders in London to stop the payments to the printer and thereby also the printing itself. The disparaging though unspecified remarks subsequently levelled at the quality of Chylinski's translation could therefore not have altered the already sealed fate of the Lithuanian Bible.

In a resolution adopted on 7 June 1663, it is stated that the collections are carried out by Chylinski and that he is to be blamed for the disturbances that have arisen. This confirms once more that the Synod relied exclusively on Krainski's assertions; while Krainski 
prevaricated and sought to evade responsibility. The Privy Council records and the wording of the letters patent show that it was not Chylinski but Krainski who filed petitions and proposals in financial matters. From Wallis' letter to Boyle, we know that the treasurers refused to pay Chylinski his stipend without express instructions from Krainski, though his stipend had been guaranteed by a Privy Council resolution.

Synod records abound in entries relating to Chylinski's irreconcilable foe, Krainski. They enable us to form at least a partial picture of his personality. References to him as the official delegate of the Synod are always respectful; and his mandate as a representative entrusted with seeking aid in England for the ravaged Lithuanian churches was renewed several times. He was nominated for this office in July 1659 by Jan Borzymowski, and in August 1660 he was dispatched to England for the first time. In the summer of 1663 , Krainski paid a visit to Lithuania; though he did not attend the Synod, he was delegated to England a second time and given an associate in the person of Mikołaj Minwid. Krainski returned to Lithuania after having given instructions to stop the printing of the Chylinski Bible, and turned over the printed sheets of the Old Testament to the Dutch Church minister and librarian Cesar Calandrini; yet at the Kedainiai convocation in June 1664 he insisted that the collection for the reconstruction of the churches and the printing of the Bible should not be abandoned. It was probably at Krainski's behest that the Synod decided to apply for a loan of Bretke's manuscript Bible from the electorial library at Königsberg, so that Chylinski's translation could be compared to it before printing. In September of the same year, Krainski was sent to England for a third time, and Chylinski's fellow-student at Franeker Gideon Reczynski was appointed ad interim to replace him as minister at Węgrów. Krainski did not succeed in having the printing of the Bible resumed. His own subjective view was not the only reason for this: in the summer of 1665 , London was in the grip of the Great Plague, the town was desolate and the printing work could probably not have been carried out anyway. Moreover, after the Restoration, many of Chylinski's patrons lost their power and influence, and those who had withstood the political storms and upheavals, Wallis and Boyle in particular, were well aware of the clash with Krainski, and probably unwilling to interfere in the policies of the delegate and the Lithuanian Calvinist Synod. When Krainski returned to Lithuania 
we do not know, but at the Synod which opened on 4 July 1666 , the day of Chylinski's death, official discontent was expressed with Krainski's neglectful performance of his duties as a delegate, his absence from the synods and his failure to render an account of his dealings. The Synod sent a letter about this to England, care of Duke Bogusław Radziwiłł. After another year, at the Vilnius Synod of 1667, Krainski professed his innocence, pointing to the English Civil War (which had long been over at the time referred to) as the reason for his absence from the synods. Though we now see, with hindsight, that Krainski was just wriggling out of responsibility and was solely concerned with his own interests, the Synod let itself be convinced and granted him permission to negotiate his salary at Węrów, where he spent most of his remaining life. From the synodal records from 1672, 1673 and 1675, we gather that he was continually engaged in pecuniary litigations. In 1672 he was accused by the seniors of the Vilnius Synod of having embezzled 1,000 florins, and precautions were taken against further losses; on several occasions, the Synod adopted resolutions calling on Krainski to reimburse greater or smaller sums. In 1675, the Synod directs that 'the Reverend Minister is to pay the sum of 587 florins due to the Church of Wegrów without any altercation at the next meeting of the Synod, under penalty of loss of his benefice. As concerns the sum of 150 florins bequeathed to the hospital by the Honourable $\mathrm{Mr}$ Szulc, the Reverend Minister and Consenior should reimburse it at the Elders' behest under the same penalty.' In a synodal memorial of 1676, it is stated that Krainski, senior of Podlasie, has rendered sufficient account to the Synod and has evidently been cleared of all charges. On a more general view, however, we cannot escape the conclusion that concern for confessional matters, the future of the Church and the enlightenment of the faithful were never prominent in Krainski's mind.

\section{Jan Krzysztof Krainski's report to the Lithuanian Calvinist} Synod, 28 May $1663{ }^{49}$ Krainski's report to the Synod on the course of the collections is extant in a copy signed by Teofil Dunin Rajecki, marshall of Lida and chairman of the Synod. The text of the report was read out at the Synod in the absence of Krainski himself, although he was in Lithuania at that time and was being hosted by Jan Borzymowski, who had organised a party at Kedainiai

${ }^{49}$ LMAB RS, F-40, b. 586, dok. 124. 
to celebrate Krainski's visit to Lithuania. Part of the report consists of a plea to be excused from attending the Synod, while another part of it is dedicated to explaining why the delegate did not succeed in having the printing of the Lithuanian Bible expunged from the list of objects of the collection. This would mean that the idea of a Lithuanian Bible did not emanate from the Synod, as Krainski had asserted in London. Krainski's account is full of inconsistencies and emotional in style, quite unlike what one would expect from an official report. He goes out of his way to accuse and reproach Chylinski, and recounts indignantly how the latter, having unexpectedly returned to London, made attempts at having the printing of the Bible resumed. In its final parts, the report contains quotations from letters written by Borzymowski to Krainski; this shows how those two ministers had united their efforts to counter Chylinski's endeavours. Borzymowski was himself the author of a translation of the New Testament, and could therefore easily be persuaded into a scheme to have his own translation printed rather than Chylinski's. The whole document breathes animosity towards Chylinski, and should therefore be approached with caution, and confronted with other sources relating to the history of the Chylinski Bible.

When Krainski arrived in London, Chylinski could already boast many achievements: he had completed his translation of the Bible and gained the support of influential patrons, the printing of the Bible had been started and a first portion of printed text had been presented to the King, and a collection was to be held towards its further printing. The delegate found it hard to adjust himself to a situation that did not match his expectations, and to reconcile his own objective of collecting money for the Lithuanian churches with the need for a Lithuanian Bible. Chylinski had certainly made a good beginning by establishing broad ties, launching the printing of the Bible and publicising his undertaking in pamphlets which also gave an overview of what the Lithuanian Protestants had achieved in the domain of publishing. The ground had been prepared for further action, but Krainski saw this as competition, and feared the Bible could swallow up the money for relief to the churches. Having manoeuvred Chylinski out of the position he held, he did not succeed in usurping his place in the circle of supporters that had already formed around the translator of the Bible, and which included many Oxford professors and members of Hartlib's entourage. To Chylinski's patrons, he remained a stranger who did not inspire 
confidence. Blinded by the idea of profiting from the benevolence of the English public and their respect for the Scriptures, to collect more money for the churches (and probably also to achieve personal gain in the process) he blocked the way not only for the printing of the Lithuanian Bible but also for the financial strengthening of the Lithuanian churches.

In conclusion To conclude, we may say that, numerous beyond expectation, the newly found documents from English libraries greatly enrich the body of sources for the history of the Chylinski Bible, and inspire hope for new findings. The prospect of hitting on more traces of Chylinski's work is quite real. By 1661-1662, Chylinski had already translated the whole Scripture. Part of the printed text of the Old Testament (up to Job 6) and the manuscript of the New Testament have come down to our days. We should not lose every hope of finding the remaining part of the Old Testament some day. We know that Chylinski intended to translate the Annotations to the Dutch Statenbijbel, an English version of which (The English and Dutch Annotations) had been published in 1657. He also intended to provide a Lithuanian metrical version of the Psalms to match the melodies used in the British Isles, and to make the Longer and Shorter Westminster Catechisms (1643) accessible to the Lithuanian reader. After his efforts to have his Bible translation printed proved ineffectual, this strong-willed and purposeful man certainly did not renounce his plans. As long as his strength allowed, he kept working at the tasks he had set himself. I would therefore like to conclude this overview of sources for the Chylinski Bible by expressing the hope that the archives of Britain will, in the course of time, yield more than one secret connected with the Chylinski Bible and the cultural history of Lithuania.

Author details

Gina Kavaliūnate is a research worker at the Department of Language History and Dialectology of the Institute of the Lithuanian Language. Her principal domains of interest are the linguistic analysis of Old Lithuanian texts and the cultural history of Lithuania.

Address: Institute of the Lithuanian Language, P. Vileišio g. 5, LT 10308, Vilnius, Lithuania.

E-mail: gina.kavaliunaite@lki.lt 
ISTORINIAI ŠALTINIAI APIE SAMUELIO BOGUSLAVO CHYLINSKIO VEIKLĄ ANGLIJOJE IR NYDERLANDUOSE BEI JOS ATGARSIUS LDK

Santrauka

\section{GINA KAVALIŪNAITE}

Straipsnyje pristatomi šiuo metu žinomi Chylinskio Biblijos istorijos šaltiniai. Tai Chylinskio laiškai, rašyti ji globojusiems asmenims, jo rèmėjų tarpusavio korespondencija, įrašai Anglijos karaliaus Slaptosios tarybos protokoluose, karaliaus isakas, skelbiantis rinkliavas lietuviškai Biblijai spausdinti ir paremti Lietuvos evangelikų reformatų bažnyčias, memorandumas dẻl šio įsako, įrašų apie brevių gavimą sąrašai, rinkliavų sąrašai, spausdinti leidiniai (Samuelio Boguslavo Chylinskio An account of the Translation of the Bible into the Lithuanian Tongue [...], Oxford: Henry Hall, 1659 ir Ratio Institutce Translationis Bibliorum in Linguam Lithvanicam [...], [Oxford, 1660/1], Jano Krainskio A Relation of the Distressed State of the Church of Christ, Professing the Protestant Religion in the Great Dukedom of Lithuania, Presented to the view of all Compassionate Christians. London, Printed in the Year of our Salvation 1661; rekomendacijos Chylinskiui A Copy of the Testimonial given to the Translator, and to the approbation of his undertaking, by several Reverend Doctors of Divinity, with the Professors of the same, and other Persons of Note, in the University of Oxford (Oksfordo universiteto profesoriu ir kitų mokslo žmonių rekomendacija anglų bei lotynų kalbomis) ir Rector Magnificus \& Senatus Academiae Frisiorum quae est Franequerae, lectori Salutem in Domino (Franekerio universiteto rektoriaus ir bibliotekininko rekomendacija); Edwardo Phippso ir Williamo Medgate'o prašymas atlyginti Chylinskio slaugymo ir laidojimo išlaidas, irašai bažnyčiu knygose. Chylinskio veiklos atspindžius LDK liudija Lietuvos evangelikų reformatų sinodalų Anglijos karaliui, jo Slaptajai tarybai ir serui Richardui Browne'ui išsiųsti laiškai, LDK evangelikų reformatų sinodų protokolai ir evangelikų reformatu pasiuntinio Anglijoje Jano Krzystofo Krainskio ataskaita apie organizuotas rinkliavas.

Nemaža dalis straipsnyje aprašomų šaltinių rasti pastaraisiais metais ir ankstesnių tyrèjų darbuose nèra minèti. Naujai rasta dokumentika papildè ankstesnių tyrimų rezultatus, sudare galimybę iš naujo įvertinti ir patikslinti kai kuriuos faktus. Jais remiantis buvo nustatyta tiksli Chylinskio mirties data ir mirties aplinkybès; nustatyta ir surasta Chylinskio palaidojimo vieta; rasta duomenų apie rinkliavų lietuviškai Biblijai spausdinti ir lietuviškoms bažnyčioms atstatyti eigą; patvirtintas daugiausia tyrèjų ižvalgomis paremtas požiūris ì Krainskio vaidmenį Chylinskio Biblijos spausdinimo sustabdymui; ivertintos ankstesnejje istoriografijoje neminètos aplinkybès, lèmusios Chylinskio Biblijos spausdinimo nutraukimą; nustatyta, kad spausdinimas buvo sustabdytas ne tik dèl Krainskio sudaromų kliūčių ir ji palaikiusio Lietuvos kalvinistų sinodo iniciatyvos: spausdinimo eigai kliude ir to meto Anglijos politinio ir visuomeninio gyvenimo aplinkybès.

Netikètai gausūs Chylinskio Biblijos istorijos šaltinių sąrašą praplètę radiniai Anglijos bibliotekose teikia vilties, kad prasmingos ir tolesnès paieškos, o tikimybė rasti daugiau pirmos lietuviškai spausdintos Biblijos vertėjo veiklos pėdsakų nemenka: 1661-1662 m. Chylinskis jau buvo išvertęs i lietuvių kalbą visą Šventaji Raštą. Iki šių dienų išliko spausdintoji Senojo Testamento dalis (iki Jobo knygos 6 skyriaus) ir Naujojo Testamento rankraštis. Nereikètų prarasti vilties surasti likusią Senojo 
Testamento rankraščio vertimo dalị. Žinoma, kad Chylinskis ketino išversti į lietuvių kalbą Generaliniu luomu Biblijos pastabas, kurių angliškas leidimas English and Dutch annotations išspausdintas 1657 m., žadejjo pagal Anglijos salyne iprastas melodijas lietuviškai sueiliuoti psalmes, lietuvių skaitytojui pateikti Didiji ir Mažaji Vestminsterio asamblejoje patvirtintus katekizmus (1643). Šis atkaklus ir savo tikslo siekiantis žmogus dirbo iki paskutinès gyvenimo dienos ir rengè žadètuosius darbus. Tad nederètu prarasti vilties, kad istorijos šaltinių archyvai ilgainiui gali atskleisti dar ne vieną Chylinskio Biblijos ir Lietuvos kultūros istorijos paslaptị. 